\title{
IMPLEMENTASI WASIAT DAN KEWARISAN \\ DALAM PERSFEKTIF HUKUM ISLAM
}

\begin{abstract}
Winarno* $^{*}$
Abstract:

The issue of will and inheritance in Islam is an issue that cannot be separated from one another. Although automatically when someone dies, inheritance law applies where the family left behind is the heir of the deceased. However, this inheritance cannot be implemented directly. In addition to the assets left by someone who dies, it is used for the cost of managing the corpse and paying off the debts left by him. On the other hand, if the deceased leaves a will on the property he left behind, then the will must be completed first and then the distribution of the inheritance can be carried out. However, the will left by someone who died must not violate the existing provisions, whether regulated in Islamic law or statutory regulations. If the legal provisions that have been regulated both in Islamic law and existing statutory regulations are violated, then the issue of will and inheritance can be considered null and void by law.
\end{abstract}

Keywords: Will, Inheritance, Islamic Law Perspective

\begin{abstract}
Abstrak
Persoalan wasiat dan kewarisan dalam Islam merupakan suatu persoalan yang tidak bisa dipisahkan antara satu dengan yang lainnya. Walaupun secara otomatis ketika meninggalnya seseorang berlaku hukum kewarisan di mana keluarga yang ditinggalkan merupakan pewaris dari yang meninggal, namun persoalan kewarisan tersebut tidak secara langsung dapat dilaksanakan. Di samping harta yang ditinggalkan oleh seseorang yang meninggal untuk biaya pengurusan jenazah dan hutang yang ditinggalkannya, di sisi lain apabila yang meninggalkan tersebut meninggalkan wasiat terhadap harta yang ditinggalkannya, maka wasiat tersebut harus diselesaikan terlebih dahulu baru pembagian harta warisan dapat dilaksanakan. Akan tetapi, persoalan wasiat yang ditinggalkan oleh seseorang yang meninggal tersebut tidak boleh menyalahi ketentuanketentuan yang telah ada, baik itu yang diatur dalam hukum Islam maupun peraturan perundang-undangan yang ada. Apabila ketentuan hukum yang telah diatur dalam hukum Islam maupun peraturan
\end{abstract}

* Institut Agama Islam Negeri Syaikh Abdurrahman Siddik Bangka Belitung, email: winarno83.stain@gmail.com 
perundang-undangan yang ada dilanggar, maka persoalan wasiat dan kewarisan tersebut bisa dianggap batal demi hukum.

Kata Kunci: Implementasi, Persfektif, Wasiat, Waris, Hukum Islam.

\section{Pendahuluan}

Manusia di dalam perjalanannya hidup di dunia mengalami tiga peristiwa yang penting, yaitu: waktu ia dilahirkan, waktu ia kawin dan waktu ia meninggal dunia. Pada waktu seorang dilahirkan tumbuh tugas baru di dalam keluarganya, demikianlah dalam artian sosiologis, ia menjadi pengembang dari hak dan kewajiban. Kemudian setelah dewasa, ia akan kawin. Ia akan bertemu dengan kawan hidupnya untuk membangun dan menunaikan dharma baktinya yaitu: tetap berlangsungnya keturunan. Di dalam bidang hukum perkawinan hal yang demikian ini, adalah suatu hal yang sangat penting, karena ada dua makhluk Allah Swt. yang selanjutnya akan menjadi satu keluarga. Bertemunya dua orang yang masing-masing jadi pengembang dari hak dan kewajiban di dalam pertalian perkawinan mempunyai akibat di dalam bidang hukum. ${ }^{1}$

Akibat-akibat ini semuanya diatur dalam hukum perkawinan, sebagaimana diperinci lebih lanjut dalam Buku I Kitab Undang-Undang Hukum Perdata. Kemudian manusia pada suatu saat akan meninggalkan dunia, peristiwa ini adalah peristiwa yang sangat penting, karena diliputi oleh suasana yang sangat rahasia dan yang menimbulkan rasa sedih. Kesedihan yang meliputi keluarga yang ditinggalkan dan rasa duka pada saudara dekatnya tersebut.

Timbul persoalan, setelah orang meninggal dunia, apakah yang terjadi dengan segala sesuatunya yang ia tinggalkan. Di dalam hal ini nampaknya perlu kita perhatikan lebih lanjut persoalan-persoalan tersebut. Oleh sebab itu dalam tulisan jurnal ini akan dibahas lebih lanjut tentang "Implementasi Wasiat dan Kewarisan dalam Persfektif Hukum Islam".

${ }^{1}$ Muhammad Amin Summa, Hukum Keluarga Islam di Dunia Islam, (Jakarta: PT. Raja Grafindo Persada, 2005), hlm. 70 


\section{Pengertian Wasiat}

Wasiat menurut pengertian bahasa mengandung beberapa pengertian, di antaranya adalah sebagai berikut:

1. Menjadikan

2. Menaruh balas kasihan

3. Menyambung

4. Memerintahkan

5. Mewajibkan dan lain-lain. ${ }^{2}$

Sedangkan wasiat menurut istilah syara' adalah "Pemberian hak kepada seseorangyang ditentukan berlakunya setelah mati, atau meninggalnya si pemberi wasiat, baik yang diwasiatkan itu berupa benda atau manfaatnya". ${ }^{3}$ Sedangkan menurut Thalib ${ }^{4}$ wasiat juga pengertian keagamaan yaitu sekurangkurangnyabagi yang beragama Islam, banyak arti wasiat itu, dalam arti "berpesan, baik menentukan sesuatu ataupun yang bersangkutan dengan harta peninggalan dalam bidang kewarisan atau setidak-tidaknya yang berhubungan dengan soal kewarisan".

Dengan kata lain, wasiat dapat diartikan pernyataan kehendak oleh seseorang mengenai apa yang akan dilakukan terhadap hartanya sesudah ia meninggal kelak. Menurut arti kata-kata dan untuk pemakaian untuk soal-soal lain di luar kewarisan, maka wasiat berarti pula nasihat-nasihat atau kata-kata yang baik yang disampaikan seseorang kepada dan untuk orang lain yang berupa kehendak orang yang berwasiat itu untuk dikerjakan terutama nanti sesudah di meninggal.

${ }^{2}$ Ibid., hlm. 128 Lihat juga Departeman Pendidikan Dan Kebudayaan, Kamus Besar Bahasa Indonesia, (Jakarta: Balai Pustaka, 1997), hlm. 1126

3 Ibrahim Hoesein, Problematika Wasiat Menurut Pandangan Islam, (Jakarta: Fakultas Hukum Universitas Indonesia, 1985), hlm. 1.

4 Sajuti Thalib, Hibah, Wasiat dan Hibah Wasiat Dalam Hubungannya Dengan Kewaritsan, (Jakarta: Fakultas Hukum Universitas Indonesia, 1985), hlm. 1. 
Sedangkan wasiat menurut pandangan imam Mazhab dan Undangundang Mesir (Undang-undang Wasiat No. 71 Tahun 1946) adalah sebagai berikut:

1. Menurut Mazhab Hanafi, wasiat adalah memberikan hak memiliki sesuatu secara sukarela (tabarru') yang pelaksanaannya ditangguhkan setelah ada peristiwa kematian dan yang memberikan, baik itu berupa barang maupun manfaat.

2. Menurut Mazhab Maliki, wasiat adalah suatu perikatan yang mengharuskan penerima wasiat dapat sepertiga harta peninggalan si pewarits sepeninggalnya atau mengharuskan penggantian hak sepertiga harta peninggalan si pewarits kepada si penerima wasiat sepeninggalnya pewasiat.

3. Menurut Undang-Undang Mesir No. 71 Tahun 1946, wasiat adalah mengalihkan hak milik harta peninggalan yang ditangguhkan kepada kematian seseorang. ${ }^{5}$

Dari beberapa defenisi yang dikemukakan di atas, bahwasanya wasiat itu baru dapat dilaksanakan apabila si pewaris telah meninggal dunia. Atau dengan kata lain sebelum orang meninggal tidak ada perkara wasiat.

\section{Dasar Hukum Wasiat}

Perkara utama dalam pembagian harta pusaka adalah menyelesaikan wasiat. Perintah untuk membuat wasiat ini disebut dari kalimat awal dalam AlQuran Surat Q.S. al-Baqarah (2): 180 sebagai berikut:

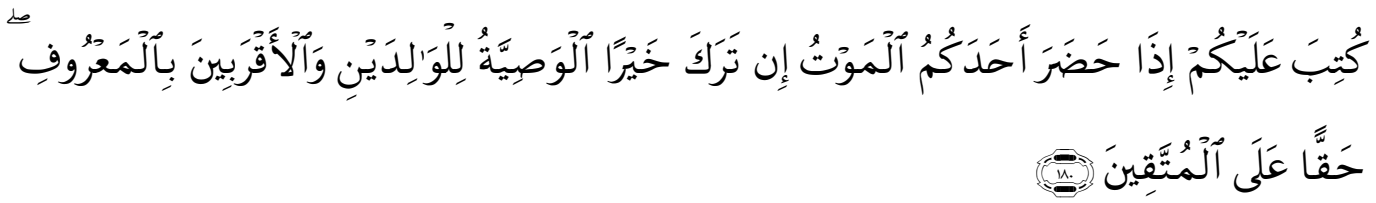

“Diwajibkan atas kamu, apabila seorang di antara kamu kedatangan (tanda-tanda) maut, jika ia meninggalkan harta yang banyak, Berwasiat

${ }^{5}$ Muhammad Idris Ramulyo, Perbandingan Pelaksanaan Hukum Kewaritsan Islam Dengan Kewaritsan Menurut Undang-Undang Hukum Perdata, (Jakarta: Sinar Grafika, 2000), hlm. 132. 
untuk ibu-bapak dan karib kerabatnya secara ma'ruf, ${ }^{6}$ (ini adalah) kewajiban atas orang-orang yang bertakwa".

Ayat di atas memberikan pelajaran kepada kita, bahwasanya ketika seseorang meninggal dunia, maka yang harus pertamakali diselesaikan setelah jenazah dikuburkan adalah persoalan wasiat. Sebab, apabila persoalan wasiat belum dilaksanakan, maka pembagian harta warisanpun belum bisa dilaksanakan. Kemudian, sekiranya kandungan wasiat diketahui tidak adil, berdosa atau ia harus diperbaiki dengan perundingan antara pihak-pihak yang terlibat, maka hal inipun dianjurkan. Hal ini sebagaimana penegasan Allah Swt. Dalam Surat Q.S. al-Baqarah (2): 102 sebagai berikut:

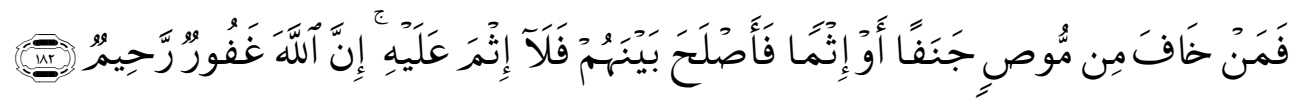

“(Akan tetapi) Barangsiapa khawatir terhadap orang yang Berwasiat itu, Berlaku berat sebelah atau berbuat dosa, lalu ia mendamaikan ${ }^{7}$ antara mereka, Maka tidaklah ada dosa baginya. Sesungguhnya Allah Maha Pengampun lagi Maha Penyayang".

Dalam kandungan ayat lain juga, bahwasanya wasiat bagi seorang suami yang meninggal dunia dan diketahui ia meninggalkan istri dan anak, maka persoalan wasiat diutamakan terhadapnya. Hal ini sejalan dengan firman Allah Swt. dalam Surat Q.S. al-Baqarah (2): 240 berikut ini:

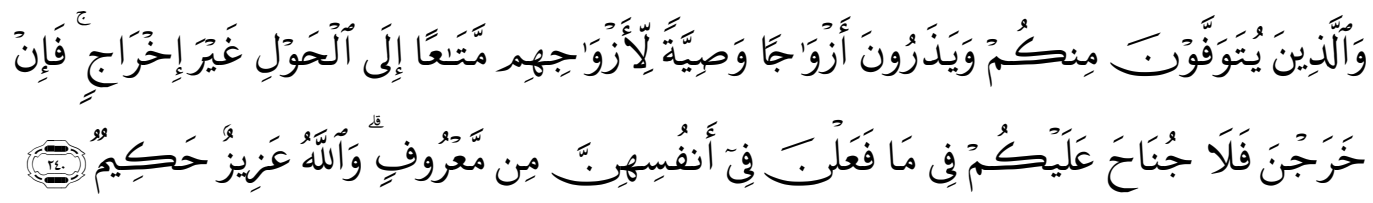

“Dan orang-orang yang akan meninggal dunia di antara kamu dan meninggalkan isteri, hendaklah Berwasiat untuk isteri-isterinya, (yaitu) diberi nafkah hingga setahun lamanya dan tidak disuruh pindah (dari rumahnya). akan tetapi jika mereka pindah (sendiri), Maka tidak ada dosa bagimu (wali atau waris dari yang meninggal) membiarkan mereka berbuat yang ma'ruf terhadap diri mereka. dan Allah Maha Perkasa lagi Maha Bijaksana".

\footnotetext{
${ }^{6}$ Ma'ruf yang dimaksud dalam ayat di atas adalah adil dan baik. Kemudian ketentuan terhadap wasiat itu tidak melebihi sepertiga dari seluruh harta orang yang akan meninggal itu.

7 Mendamaikan maksudnya adalah menyuruh orang yang Berwasiat Berlaku adil dalam Mewasiatkan sesuai dengan batas-batas yang ditentukan syara'.
} 
Selanjutnya, dari penjelasan ayat di atas dapat dipahami yaitu namanama penerima harta pusaka yang dinyatakan dalam wasiat hendaklah termasuk "orang-orang yang terkait dengan sumpah" orang yang berwasiat, seperti anak angkat, anak tiri, atau apa yang dikatakan "tangan-tangan kanan kamu memiliki", seperti yang diisyaratkan oleh ayat al-Quran Surat Q.S. anNisa' (4): 33 berikut ini:

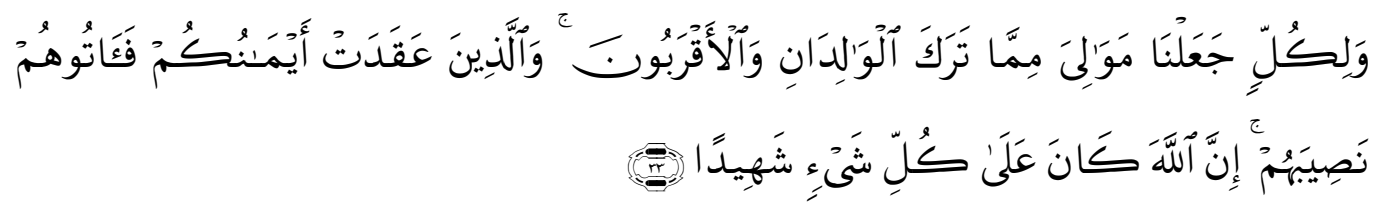

“Bagi tiap-tiap harta peninggalan dari harta yang ditinggalkan ibu bapak dan karib kerabat, Kami jadikan pewaris-pewarisnya. ${ }^{8}$ Dan (jika ada) orang-orang yang kamu telah bersumpah setia dengan mereka, Maka berilah kepada mereka bahagiannya. Sesungguhnya Allah menyaksikan segala sesuatu".

Dalam hal wasiat, maka untuk keabsahan wasiat tersebut maka diperlukan dua orang saksi. Adapun saksi tersebut harus mempunyai jiwa yang adil, sebab orang yang tidak adil tidak sah menjadi saksi. Adapun alternatif terakhir berkenaan dengan saksi ini, kalau diragukan kesaksiannya, maka ditempuh dengan jalan sumpah. Karena dengan jalan sumpah ini merupakan alternatif akhir dalam syariat Islam. Hal ini telah diatur oleh Allah Swt. dalam Surat Q.S. al-Maidah (5): 106 berikut ini:

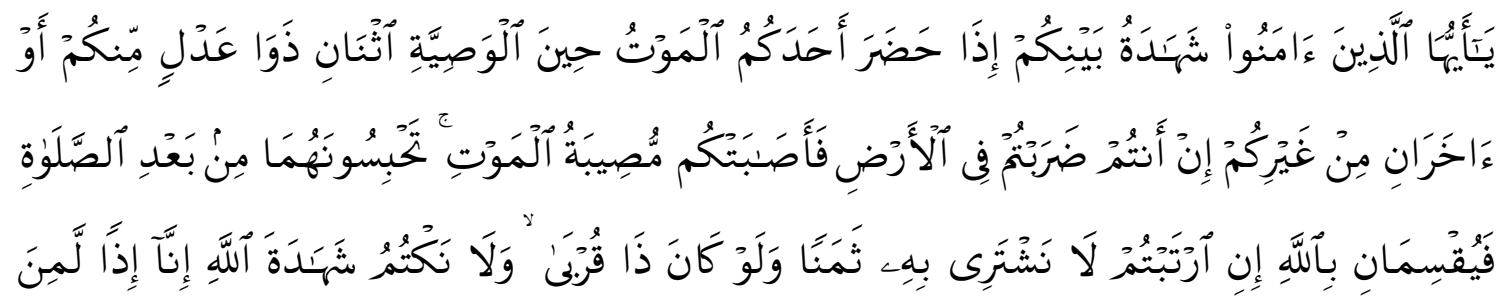

"Hai orang-orang yang beriman, apabila salah seorang kamu menghadapi kematian, sedang Dia akan berwasiat, Maka hendaklah (wasiat itu) disaksikan oleh dua orang yang adil di antara kamu, atau

8 Orang-orang yang termasuk ahli waris dalam ayat di atas bisa dilihat secara lebih rinci pada Surat An-Nisaa': 11-12. 
dua orang yang berlainan agama dengan kamu9, jika kamu dalam perjalanan dimuka bumi lalu kamu ditimpa bahaya kematian. kamu tahan kedua saksi itu sesudah sembahyang (untuk bersumpah), lalu mereka keduanya bersumpah dengan nama Allah, jika kamu ragu-ragu: "(Demi Allah) Kami tidak akan membeli dengan sumpah ini harga yang sedikit (untuk kepentingan seseorang), walaupun Dia karib kerabat, dan tidak (pula) Kami Menyembunyikan persaksian Allah; Sesungguhnya Kami kalau demikian tentulah Termasuk orang-orang yang berdosa".

Dari semua ayat-ayat di atas, menunjukkan berbagai macam tata cara dalam urusan wasiat. Semuanya memberikan gambaran kepada manusia untuk melaksanakan hal tersebut, baik dari tata caranya hingga pada akhirnya hukum yang dikeluarkan daripada persoalan wasiat tersebut.

\section{Hukum Wasiat}

Hukum wasiat dapat ditinjau dari beberapa kondisi, yaitu:

1. Wajib

Berwasiat itu hukumnya wajib, apabila wasiat itu untuk hak-hak Allah Swt. yang dilalaikan oleh si pewasiat, misalnya: Zakat yang belum dibayar, kafarah, nadzar, puasa, haji dan lain-lainya atau sebagai pemenuhan hak-hak sesama yang tidak diketahui oleh si pewasiat sendiri.

2. Sunah

Untuk orang-orang yang tidak menerima pusaka atau untuk motif sosial, seperti berwasiat kepada fakir miskin, anak yatim dalam rangka menambah amal (bertaqarub) kepada Allah Swt., memberi sumbangan kepada pembangunan rumah-rumah Ibadah, Madrasah-madrasah, sumbangan kepada kaum kerabat yang kekurangan dan lembagalembaga sosial, maka wasiat semacam ini disunahkan dalam syariat Islam.

\footnotetext{
${ }^{9}$ Dalam hal kesaksian, mengambil orang lain yang tidak seagama dengan kamu sebagai saksi dibolehkan, bila tidak ada orang Islam yang akan dijadikan saksi.
} 


\section{Winarno}

3. Haram

Berwasiat untuk kepentingan maksiat seperti berwasiat untuk mendirikan tempat-tempat perjudian, pencurian, pelajuran dan sebagainya maka wasiat semacam ini diharamkan.

4. Makruh

Berwasiat kepada keperluan lain-lain dengan wasiat itu mereka akan bertambah gila dan tambah melakukan maksiat, misalnya berwasiat kepada anak yang ketagihan narkotika, hingga diberikan modal untuk membeli keperluan anak tersebut. Apabila dengan wasiat itu menjadi sembuh, maka menjadi makruh hukum wasiat tersebut, namun hal ini tidak terlepas dari perbedaan para ulama.

5. Mubah

Berwasiat kepada kaum kerabat atau tetangga yang mana penghidupan mereka tidak kekurangan hukumnya mubah. ${ }^{10}$ Namun apabila dialihkan kepada ahli warits terdekat bagaimana hukumnya? Menurut Hazairin ${ }^{11}$ boleh berwasiat kepada ahli warits dengan alasan yang mendesak karena perlu biaya pengobatan yang besar, biaya pendidikan anak-anak yang masih kecil-kecil dan perlu biaya banyak, sedangkan yang lain sudah cukup mampu. Maka berwasiat kepada ahli warits terdekat semacam ini lebih diutamakan daripada kepada kerabat dekat yang sudah berkecukupan.

\section{Syarat dan Rukun Wasiat}

Dalam persoalan wasiat, maka ada empat macam rukun yang harus terpenuhi sebelum wasiat itu dilaksanakan. Adapun rukun wasiat tersebut adalah sebagai berikut:

1. Harus ada orang yang berwasiat (mushi), harus memenuhi persyaratan sebagai berikut:

\footnotetext{
${ }^{10}$ Fatchur Rahman, Ilmu Warits, (Bandung: Al-Ma'arif, 1975), hlm. 567.

${ }^{11}$ Hazairin (a), Hukum Kewaritsan Bilateral Menurut Al-Qur'an dan Hadits, (Jakarta: Tintamas, 1982), hlm. 57-58.
} 

a. Baligh (dewasa)
b. Berakal sehat (aqli)
c. Bebas menyatakan kehendaknya
d. Merupakan tindakan tabarru' (darma sukarela atau amal)
e. Tidak seseorang yang dibawah pengampunan (curatele)
f. Beragama Islam

2. Harus ada seseorang atau badan hukum yang menerima wasiat (musha lahu). Dan orang yang menerima wasiat tersebut harus memenuhi syarat-syarat sebagai berikut:

a. Harus dapat diketahui dengan jelas siapa orang atau badan hukum yang menerima wasiat itu, nama orang tersebut, badan organisasi tertentu atau masjid-masjid.

b. Telah wujud (ada) pada saat wasiat dinyatakan ada sebenarnya atau ada suara juridis misalnya anak yang masih dalam kandungan

c. Bukan tujuan kemaksiatan

3. Sesuatu yang diwasiatkan (musha bihi), adapun syarat-syaratnya adalah sebagai berikut:

a. Dapat berlaku sebagai harta warisan baik benda bergerak maupun benda tak bergera, atau dapat menjadi obyek perjanjian.

b. Benda itu sudah ada (wujud) pada waktu diwasiatkan.

c. Hak milik itu betul-betul kepunyaan si pewasiat (mushi).

4. Lafaz atau ucapan wasiat (sighat)

Setelah rukun tersebut terpenuhi, maka ada syarat-syarat pula yang harus dipenuhi. Untuk sahnya suatu wasiat dapat dipergunakan segala perbuatan yang memberi pengertian secara lisan, dapat pula berbentuk tulisan, dapat dimengerti oleh orang yang tidak bisa berbicara atau menulis. ${ }^{12}$ Pada dasarnya wasiat menurut syariat Islam memiliki syarat-syarat tertentu.

12 Ahmad Azhar Basyir, Hukum Islam (Seri Fiqh Islam) Tentang Perkawinan Campur, Adopsi dan Wasiat, (Bandung: Al-Ma'arif, t.t), 42. 
Di samping itu hak-hak wasiat dari seorang muslim memiliki batasanbatasan tertentu pula. Pembatasan-pembatasan tersebut meliputi:

1. Menyangkut subyeknya. Menurut golongan Ahlul al-Sunnah orang-orang yang mendapat wasiat tidak boleh ahli warits dari pemberi wasiat. Hal ini sejalan pula dengan pendapat imam yang lain.

2. Menyangkut jumlahnya. Menurut golongan Ahlul al-Sunnah jumlah wasiat tidak boleh melebihi sepertiga jumlah harta peninggalan. Dalam hal ini harta peninggalan tersebut harus sudah dikurangi hutangpiutang si mati dan biaya penguburan mayat.

Sedangkan wasiat dapat dikatakan sah apabila memenuhi syarat-syarat sebagai berikut:

1. Orang yang memberi wasiat (pewasiat) sudah akil baligh, mempunyai pikiran sehat, benar-benar berhak atas harta benda yang akan diwasiatkan. Disamping itu si pewasiat tidak berada di bawah pengaruh yang tidak menguntungkan seperti: tertipu, terpaksa dan keadaankeadaan lain yang sejenis.

2. Orang yang menerima wasiat harus ada pada saat wasiat tersebut dilakukan atau penerima wasiat sudah atau masih ada pada saat pemberi wasiat meninggal dunia. Adapun syarat yang kedua ini akan timbul perbedaan pendapat dikalangan ulama apabila penerima wasiat tersebut juga sebagai ahli warits, dalam artian penerima wasiat berkedudukan ganda.

3. Ketentuan jumlah yang boleh diwasiatkan. Harta peninggalan hanya boleh diwasiatkan tidak lebih dari sepertiganya.

4. Pernyataan yang jelas. ${ }^{13}$ Dalam hal ini pemberi wasiat menyatakan dengan jelas mengenai isi wasiatnya di hadapan dua orang saksi. Khusus mengenai pernyataan yang jelas tidak diharuskan secara tertulis, kecuali pemenuhan terhadap ketentuan hukum setempat.

13 Zainuddin Ali, Hukum Perdata Islam di Indonesia, (Jakarta: Sinar Grafika, 2009), hlm. 142. Bandingkan dengan Muhammad Amin Summa, Hukum Keluarga.., hlm. 129. Lihat juga Q. 5 Al-Maidah: 106 


\section{Tinjauan Umum tentang Waris}

Menurut hukum kewarisan bilateral terdapat tiga prinsip kewarisan, yaitu: Pertama, ahli waris perempuan sama dengan laki-laki dapat menutup ahli waris kelompok keutamaan yang lebih rendah. Selama masih ada anak, baik laki-laki maupun perempuan, maka datuk ataupun saudara baik laki-laki maupun perempuan sama-sama ter-hijab. Kedua, hubungan kewarisan melalui garis laki-laki sama kuatnya dengan garis perempuan. Karenanya penggolongan ahli waris menjadi ashabah dan zawu al-arham tidak diakui dalam teori ini. Ketiga, ahli waris pengganti (mawali) selalu mewaris, tidak pernah tertutup oleh ahli waris lain (utama). Jadi, cucu dapat mewaris bersama dengan anak manakala orang tuanya meninggal lebih dulu daripada kakeknya dan bagian yang diterimanya sama besarnya dengan yang diterima oleh orang tuanya (seandainya masih hidup). Keberadaan mawali ini merupakan konsep yang benar-benar baru dalam ilmu faraid (waris) dan lebih mencerminkan keadilan.

Bentuk kekerabatan dalam hukum Islam sangat menentukan azas yang berlaku dalam hukum kewarisan. Dalam Al-Quran maupun Hadis memang tidak menjelaskan tentang struktur kekerabatan tertentu menurut hukum Islam. Namun demikian dalam realitasnya kita dihadapkan berbagai macam bentuk susunan kekerabatan, meliputi: patrilineal, matrilineal, dan bilateral yang masing-masing memiliki implikasi terhadap hukum waris Islam. ${ }^{14}$

Dengan beragam bentuk kekerabatan yang berlaku dalam masyarakat, bentuk kekerabatan bagaimana yang sesuai dengan hukum warits Islam. Bagi masyarakat Indonesia sistem bilateral dipandang lebih cocok, selain lebih mencerminkan keadilan, juga sesuai dengan semangat Al-Quran. Sebab hukum warits yang berlaku selama ini adalah patrilineal, berasal dari kalangan Sunni

14 Hazairin (a), Hukum Kewarisan..., hlm. 11 
Winarno

yang banyak dipengaruhi oleh kultur Arab. Sehingga banyak kendala ketika menerapkan pada kultur yang berbeda.

\section{Hukum Kewarisan Bilateral}

Membicarakan tentang kewarisan bilateral tidak bisa dilepaskan dari sosok Hazairin yang dikenal sebagai pencetus ide bentuk kewarisan bilateral. Kiprah Hazairin lebih dikenal dalam bidang ilmu hukum, terlebih dalam hukum adat. Selain itu pengetahuannya tentang tentang hukum Islam juga begitu mendalam. Melalui keahliannya dalam bidang hukum adat dan hukum Islam inilah, senat guru besar Universitas Indonesia mengukuhkan dirinya sebagai guru besar hukum adat dan hukum Islam pada fakultas hukum pada tahun 1952. Dengan keahliannya dalam kedua bidang hukum ini, ia tahu betul bagaimana kondisi hukum Islam di Indonesia bila dikaitkan dengan hukum adat. Teori Receptie yang dicetuskan oleh Snouck Hurgronje pada akhir abad XIX telah menjadikan hukum Islam tersingkir oleh hukum adat. ${ }^{15}$

Oleh karena itu Hazairin tidak segan-segan lagi untuk menyebut teori ini sebagai "teori Iblis". Sebagai sanggahan atas teori ini ia kemudian mencanangkan teori Receptie Exit. Yang kemudian ditindak lanjuti oleh muridnya, Sajuti Thalib, SH, dengan teori Receptie a Contrario. ${ }^{16}$

Pemikirannya tentang hukum kewarisan yang terkenal dengan teori hukum kewarisan bilateral menurut Al-Qur'an telah dipresentasikan pada tahun 1957. Dalam teori ini Hazairin mempertanyakan kebenaran hukum kewarisan yang dianut kalangan Sunni yang bercorak patrilineal bila dihadapkan dengan Al-Qur'an. Dengan keahliannya dalam bidang hukum adat dan antropologi sosial Hazairin mengkaji ayat-ayat tentang perkawinan dan kewarisan. Menurutnya, Al-Qur'an hanya menghendaki sistem sosial yang bilateral. Dengan demikian hukum kewarisan yang digariskan di dalamnya

${ }^{15}$ Hazairin (b), Hukum Kekeluargaan Nasional, Cet. Ke-2, (Jakarta: Tintamas, 1968), hlm. 5

${ }^{16}$ Djuhana S. Pradja, Pengantar Hukum Islam di Indonesia: Perkembangan dan Pembentukan, (Bandung: Rosda Karya, 1994), hlm. 102 
juga bercorak bilateral, bukan patrilineal seperti yang biasa dikenal selama ini. Hazairin telah memberikan pemahaman yang baru terhadap hukum kewarisan dalam Islam secara total dan komprehensif dengan asumsi dasar sistem bilateral yang di kehendaki al-Quran. Tentu saja sistem ini mempunyai dampak sosial yang luas bila dapat diterapkan dalam kehidupan. Yang menarik, agaknya teori ini lebih dekat dengan rasa keadilan dalam masyarakat kita, bila dibandingkan dengan sistem kewarisan bercorak patrilineal yang selama ini dikenal.

Sistem kewarisan patrilineal yang dianut kalangan Sunni sebenarnya terbentuk dari struktur budaya Arab yang bersendikan sistem kekeluargaan yang bercorak patrilineal. Pada masa terbentuknya fiqh, ilmu pengetahuan mengenai bentuk-bentuk masyarakat belumlah berkembang. Sehingga para fuqaha dalam berbagai mazhab fiqh belum memperoleh perbandingan mengenai berbagai sistem kewarisan dalam berbagai bentuk masyarakat. Oleh karena itu tidaklah mengherankan bila hukum kewarisan yang kemudian disusun bercorak patrilineal. ${ }^{17}$

Menurut fiqh Sunni, terdapat tiga prinsip kewarisan: Pertama, ahli warits perempuan tidak dapat menghijab (menghalangi) ahli warits laki-laki yang lebih jauh. Contohnya, ahli warits anak perempuan tidak dapat menghalangi saudara laki-laki. Kedua, hubungan kewarisan melalui garis laki-laki lebih diutamakan daripada garis perempuan. Adanya penggolongan ahli warits menjadi ashabah dan zawu al-arham merupakan contoh yang jelas. Ashabah merupakan ahli warits menurut sistem patrilineal murni, sedangkan zawu alarham adalah perempuan-perempuan yang bukan zawu al-faraid dan bukan pula ashabah. ${ }^{18}$ Ketiga, tidak mengenal ahli waris pengganti, semua mewaris karena dirinya sendiri. Sehingga cucu yang orang tuanya meninggal lebih dulu

\footnotetext{
${ }_{17}$ Hazairin (c), Hendak Ke Mana Hukum Islam, Cet. Ke-III, (Jakarta: Tintamas, 1976), hlm. $11-12$

${ }^{18}$ Hazairin (a), Hukum Kewarisan..., hlm. 76-77
} 
Winarno

daripada kakeknya, tidak akan mendapat warisan ketika kakeknya meninggal. Sementara saudara-saudara dari orang tua sang cucu tetap menerima warisan.

Menurut pengamatan Hazairin, sistem kewarisan sunni yang bercorak patrilineal tersebut kurang sesuai dengan rasa keadilan masyarakat di Indonesia yang umumnya bercorak bilateral. Bagi masyarakat patrilineal seperti Batak, bukan berarti tidak ada konflik dengan sistem kewarisan kalangan sunni. Apalagi bagi masyarakat matrilineal seperti Minangkabau, tentu lebih berat lagi untuk menerima sistem kewarisan ini. Hal inilah yang menggugah Hazairin untuk memikirkan sistem bagaimanakah yang dikehendaki oleh Al-Qur'an. Menurutnya, tidak mungkin al-Quran memberikan ketentuan yang tidak adil. Berdasarkan pengamatannya terhadap beberapa ayat tentang perkawinan dan kewarisan akhirnya dia mempunyai keyakinan bahwa Al-Qur'an menghendaki sistem kekeluargaan yang bilateral.

Adapun dasar yang mendukung teorinya adalah Q.S. an-Nisa' (4): 22-24, juga didukung oleh ayat-ayat 11, 12, 176 dalam surat yang sama. Dari ayat 2224 diperoleh petunjuk bahwa semua bentuk perkawinan sepupu tidaklah dilarang, baik cross-cousins maupun parallel cousins. Dengan dibolehkannya perkawinan sepupu ini berarti tanggallah syarat exogami yang menjadi benteng bagi sistem clan dalam masyarakat yang patrilineal dan matrilineal. Jika clan telah tumbang maka timbullah masyarakat yang bercorak bilateral. Ayat 11 menjadikan semua anak, baik laki-laki maupun perempuan sebagai ahli warits bagi ayah dan ibu. Hal ini merupakan bentuk sistem bilateral, karena dalam patrilineal prinsipnya hanya anak laki-laki yang berhak mewaritsi sedangkan dalam sistem matrilineal anak-anak hanya mewaritsi dari ibunya, tidak dari bapaknya. Kemudian ayat 12 dan 176 juga mendukung sistem bilateral, yaitu dengan menjadikan saudaranya ahli warits bagi saudaranya yang mati punah (tak berketurunan), tidak dibedakan apakah saudara itu laki-laki atau perempuan. ${ }^{19}$

19 Ahmad Sukris Sarmadi, Transendensi Keadilan Hukum Waris Islam Transformatif, Cet. Ke-I, (Jakarta: Rajawali Press, 1997), hlm. 266 
Berikutnya ayat 7, 8, 11, 12, dan 176 memberikan ketentuan bahwa sistem kewarisan yang dikehendaki oleh al-Quran di samping bilateral adalah individual. Maksudnya masing-masing ahli warits berhak atas bagian yang pasti dan bagian-bagian tersebut wajib diberikan kepada mereka. Di sini terdapat istilah nasiban mafrudan, fa atuhum nasibuhum, al-qismah, di samping terdapat bagian-bagian tertentu (furud al-muqaddarah) dalam ayat-ayat tersebut. Jadi sistem kewarisan yang dikehendaki dalam al-Quran adalah individual bilateral. Dengan teorinya ini Hazairin agaknya ingin mengajak umat Islam untuk memperbaharui pemahaman terhadap ayat-ayat tentang kewarisan.

\section{Tanggapan Pro dan Kontra}

Gagasan tentang sistem kewarisan bilateral yang dicetuskan Hazairin ternyata mendapat tanggapan pro dan kontra di kalangan umat Islam Indonesia. Fenomena ini merupakan hal yang wajar apabila ada yang masih belum bisa menerima ide pembaharuan yang dia kemukakan. Apalagi dengan menrekonstruksi sesuatu yang telah lama mapan, akan sulit diterima meskipun hal yang baru ini cukup rasional dan argumentatif. Namun bukan berarti mereka yang menolak termasuk tidak rasional. Mereka yang menolak di samping didasarkan pada pengetahuan tentang sistem kewarisan yang selama ini mereka ketahui, juga tidak sedikit pula yang menyikapi dengan penuh curiga terhadap sesuatu yang dianggap baru.

Meskipun pada awalnya banyak terjadi penolakan, namun tidak sedikit pula yang bersimpati dan mendukung ide kewarisan bilateral ini. Bahkan dewasa ini hampir setiap kali membahas tentang ilmu warits hampir tidak melepaskan pemikiran Hazairin. Barangkali penolakan yang terjadi terhadap sistem kewarisan bilateral lambat laun berkurang seiring dengan semakin berkembangnya ilmu pengetahuan dan terbukanya masyarakat untuk menerima perubahan.

Dukungan terhadap pendapat Hazairin telah banyak dikemukakan dalam berbagai kajian ilmiah. Keberatan terhadap teori ini agaknya lebih 
disebabkan ketidakberanian mereka mengoreksi cara tafsir mazhab sunni yang lebih condong kepada sistem patrilineal dan terlanjur disakralkan.Untuk itu agar pemikiran Hazairin dapat diterima di kalangan sunni yang konservatif ini manakala dia mampu memahami bahwa sistem kewarisan Sunni merupakan salah satu hasil penalaran intelektual sebagaimana halnya yang dilakukan Hazairin. ${ }^{20}$

Terlepas adanya sikap pro dan kontra di atas, perlu diketahui bahwa pemikiran Hazairin ini telah turut memperkaya perkembangan hukum Islam di Indonesia terlebih tentang ilmu waris. Kompilasi Hukum Islam (KHI) sebagai bentuk kodifikasi hukum Islam di Indonesia agaknya tidak luput dari pengaruh Hazairin, seperti telah diaturnya ketentuan tentang ahli warits pengganti pada pasal 185.

\section{Kesimpulan}

Berangkat dari deskripsi di atas, maka dapat disimpulkan bahwasanya sebelum harta warisan di bagi, maka terlebih utama yang harus dilaksanakan adalah melaksanakan wasiat dari orang yang meninggal. Namun, sebelum itu semua dilaksanakan maka kewajiban-kewajiban utama terhadap almarhum harus ditunaikan, seperti biaya penguburan dan lain sebagainya. Apabila hal ini sudah terlaksana, maka harta warisanpun boleh dibagi terhadap orangorang yang berhak menerimanya.

Mengenai pembagian harta warisan, akhirnya, interpretasi terhadap sistem kewarisan bilateral pada dasarnya merupakan bentuk ketidak puasan menerima sistem kewarisan Sunni klasik. Doktrin Sunni yang selama ini dipegang oleh umat Islam di Indonesia bercorak patrilineal, padahal yang dikehendaki Al-Qur'an adalah sistem kewarisan bilateral. Penafsiran hukum warits yang bercorak patrilineal kalangan Sunni sebenarnya merupakan pengaruh dari kultur bangsa Arab yang bercorak patrilineal.

${ }^{20}$ Ibid., hlm. 278 


\section{REFERENCES}

\section{Al-Quran Al-Karim}

Ali, Zainuddin. Hukum Perdata Islam di Indonesia. Jakarta: Sinar Grafika. 2009.

Basyir, Ahmad Azhar. Hukum Islam (Seri Figh Islam) Tentang Perkawinan Campur Adopsi dan Wasiat. Bandung: al-Ma'arif. T.T.

Departemen Agama. al-Quran dan Terjemahannya. Jakarta: Bumi Restu. 1974.

Departeman Pendidikan dan Kebudayaan. Kamus Besar Bahasa Indonesia. Jakarta: Balai Pustaka. 1997.

Hazairin. Hukum Kekeluargaan Nasional. Cet. Ke- II. Jakarta: Tintamas. 1968.

--------, Hendak Kemana Hukum Islam. Cet. ke- III. Jakarta: Tintamas. 1976.

-------, Hukum Kewaritsan Bilateral Menurut al-Quran dan Hadits. Cet. ke-V. Jakarta: Tintamas. 1982.

Hoesein, Ibrahim. Problematika Wasiat Menurut Pandangan Islam. Jakarta: Fakultas Hukum Universitas Indonesia. 1985.

Mudzhar, Muhammad Atho. Letak Gagasan Reaktualisasi Hukum Islam Munawir Sjadzali di Dunia Islam. Jakarta: Paramadina dan IPHI. 1995.

Pradja, Djuhana S. Pengantar Hukum Islam di Indonesia: Perkembangan dan Pembentukan. Cet. ke- II. Bandung: Rosda Karya. 1994.

Rahman, Fatchur. Ilmu Warits. Bandung: al-Ma'arif. 1975.

Ramulyo, Muhammad Idris. Perbandingan Pelaksanaan Hukum Kewaritsan Islam Dengan Kewaritsan Menurut Undang-Undang Hukum Perdata. Jakarta: Sinar Grafika. 2000.

Sarmadi, Ahmad Sukris. Transendensi Keadilan Hukum Waris Islam Transformatif. Cet. Ke- I. Jakarta: Rajawali Press. 1997.

Summa, Muhammad Amin. Hukum Keluarga Islam di Dunia Islam, Jakarta: PT. Raja Grafindo Persada. 2005.

Thalib, Sajuti. Wasiat dan Hibah Dalam Hubungannya Dengan Kewaritsan, Jakarta: Fakultas Hukum Universitas Indonesia. 1985. 